\title{
LOCALITY-BASED AND PLACE-BASED DEVELOPMENT IN THEORY AND PRACTICE - AN EXAMPLE OF THE HUNGARIAN COUNTRYSIDE
}

\author{
József LENNERT ${ }^{\mathrm{a}}$, Bálint CSATÁRI ${ }^{\mathrm{b}}$, Jenő Zsolt FARKAS ${ }^{\mathrm{a}}$, Dávid \\ MEZÖSZENTGYÖRGYI ${ }^{\mathrm{c}}$, \\ ${ }^{\text {a }}$ MTA Research Centre for Economic and Regional Studies, Institute for Regional Studies (MTA KRTK
RKI), e-mail: lennert.jozsef@krtk.mta.hu, farkas.jeno@krtk.mta.hu
b retired senior research fellow, e-mail: csatarib@t-online.hu
${ }^{\mathrm{c}}$ National Agricultural Advisory, Educational and Rural Development Institute, e-mail:
mezoszentgyorgyid@nakvi.hu
}

Cite this article: Lennert, J., Csatári, B., Farkas, J.Z., Mezőszentgyörgyi, D. (2015). Locality-based and place-based development in theory and practice - an example of the Hungarian countryside. Deturope, 7 , 2: $14-27$

\begin{abstract}
Local development has been always considered an important instrument in the renewal of the rural economy, society and settlements, but recent changes of rural areas led to the conceptual expansion of the term. Besides locality-based development, the significance of the novel concept of place-based development has also been recognised. Place-based development not only takes the local characteristics into account, but tries to harmonise the development processes of the different sectors and territorial levels. The core of place-based approach is the well-coordinated, multilateral and continuous communication between the actors and institutes from different territorial levels and different sectors. Our paper provides an overview of the concepts of locality-based and place based development, and investigates their applicability to the development of the Hungarian rural areas. The presented results of a survey which involved the experts in the Hungarian National Rural Network provide additional information about the Hungarian rural development and the necessity of place-based approach.
\end{abstract}

Keywords: locality-based development, place-based development, rural areas, rural development, Hungarian National Rural Network

\section{INTRODUCTION}

In the second half of the twentieth century European rural areas have undergone a drastic change in both the market and planned economies. Agriculture, the former backbone of rural economy, lost its dominant role in employment and its ability to sustain local population has been drastically reduced. Many rural localities are not attractive for the new, post-fordist industries and suffer from high long-term unemployment. With no barriers before it, globalisation can also freely form the countryside. Some of its processes threaten the local values and traditions, while others can lead to the renewal of the countryside. The growing global interest for sustainable living, fair-trade or locally produced food, local specialities and 
generally local heritage can open the door for new approaches with an emphasis on local characteristics.

Local developments have always been considered an important instrument in the renewal of the rural economy, society and settlements. However, recent changes of rural areas necessitated the conceptual expansion of the term and further increased its significance. Nowadays developments are not only local in the sense that an investment, project or program carried out in a certain locality, but locality-based with a deeper connection to the local level. For example, the idea for the project or program can originate from the local community, the investment or project may take the geographical characteristics of the localities into account, the investors and project-makers seek for the agreement and support of the local community and try to involve them in the decision-making process. But most importantly, the overall impact of the development to the selected (rural) locality has to be positive with measurable outputs which can be assessed through complex evaluation methods, and it has to be in accordance with the long-term development concepts of the locality. Locality-based developments have to meet with many requirements: to stimulate the local economy, to emphasize sustainability, to provide new workplaces and to help the integration into the regional economy. Fulfilling these needs resulted in locally applicable rural planning and development methods, some of which later integrated into the LEADER type development models, in accordance with the increasing role of rural development within the EU in the last two decades.

In the new millennia, these main goals best represented in the complex strategic planning document Agenda 2020. The authors of the Agenda 2020, besides acknowledging the significance of locality-based development, also emphasized the importance of place-based development (Csatári, 2011; Zaucha - Swiatek - Stanczuk-Olejnik, 2013). The main concept behind the place-based approach is that the renewal, development and closing up of rural regions will not be successful, if the planning and development process in other sectors (e.g. social) do not take the local characteristics, the differences in needs, possibilities and innovative capacities into account. The experiences of the earlier Leader programmes, which have already proved to be effective, can help to integrate the place-based approach into the projects. The place-based approach institutionalised with the introduction Community-led Local Development (CLLD) groups.

The aim of this study is to introduce the concepts of locality-based and place-based development and to overview their applicability in the present and future framework of the Hungarian rural development. The empirical data of this study collected during a survey 
involving the experts in the registry of the Hungarian National Rural Network in the spring of 2014 (Kovách - Czibere, 2014; Csatári - Farkas - Lennert, 2014).

\section{APPROACHES OF LOCALITY AND LOCALITY-BASED DEVELOPMENT IN DIFFERENT FIELDS OF SCIENCES}

One might think that the idea of taking the local characteristics into account is evident and does not require special attention, but it is enough to recall some recent historical examples to realize: this is not the truth. Both during the Fordist economic paradigm and in the socialist planned economy the different localities are considered as a natural space to carry out investments following a universal scheme. Some attempts of the socialist regimes ignored even the fundamental natural physical limits (like cotton plantations in Hungary). These extreme cases of geographical nihilism are nowadays the targets of mockery for a good reason.

However, because of their diverseness, taking the local characteristics into consideration is not an easy task. The attributes and differences of localities are investigated by a wide range of fields of studies. Each field of study uses different methodology and approach for spatial analysis. The lack of synthesis between the different fields and their research results can be held partially responsible for the failure of local developments in many cases, especially in Hungary. The four most important fields of studies in this aspect are geography, sociology, economics and public administration, but politology, ethnography and other social sciences also include spatial considerations.

Geography is known as the primary study of space. During its course of development, it mainly focused on the descriptive analysis of unique places for a long time. Besides that, geography also studies the properties of abstract space and tries to uncover the laws behind the patterns of spatial phenomena. The necessity to take the geographical characteristics into account often mentioned in the European and national development strategies, but we cannot talk about geographic characteristics in general. Geography has two main branches (physical geography and human geography) with features connecting it to both natural and social sciences. For a long time mostly only the physical geographic characteristics were taken into consideration, but recently the developers started to recognise the importance of human geography too.

Sociology is the academic study of social behaviour, and examines the structure, characteristics and relationship networks of society. One of its branches, rural sociology, 
which main concerns are the characteristics of rural society, is especially important for the locality-based and place-based development.

In economics (especially in regional economics), spatial approach appeared first in the location theories. Location theory is concerned with the geographic location of different types of economic activities, and the determinants behind the patterns. Traditional location factors include, for example, physical geographic attributes and accessibility (distance from markets). With the post-Fordist paradigm shift, the role and acknowledgement of non-traditional location factors (e.g. local knowledge, cultural heritage, and preserved natural environment) increased. While economics tend to create laws for abstract space, the importance of geographic space was also recognised recently by significant economists, e.g. Paul Krugman (1998). Krugman also identified (and illustrated with examples) a previously overlooked factor for the location of economic activities: coincidence (Krugman, 1991).

Public administration and legislation (as an academic field and as a practice) can be viewed as the application of the knowledge of the aforementioned academic studies. Public administration has a key role in identifying and delimiting certain localities. Every local community has its own perception about its surroundings and its boundaries, which are based on the geographic, social and economic characteristics. The deeply embedded local identities connected to certain regions (Őrség, Kiskunság, Bereg, Ormánság) can be mobilized to contribute to locality-based development. In order to utilize these positive energies, the administrative divisions should reflect to the mental image of the localities as much as possible. Based on the common methodology of the different academic fields, each member state places the emphasis on different characteristics and uses different criteria to describe and delimitate the localities (e. g. rural areas). A delimited locality is suitable for locality-based development only if it has certain homogeneity, distinguishable functions (residential area, agricultural area, recreational area) and it is in accordance with the perception of the locals. In Hungary, the lack of a well-functioning micro-region system is a big hindrance for the rural development. The creation of the new Hungarian micro-regional system (járás system) could resolve this issue, but unfortunately these micro-regions mostly fulfil administrative roles and do not catalyse local development.

\section{THE CONCEPT OF PLACE-BASED DEVELOPMENT}

The changes in the concept of locality-based development and in the priorities of the European rural development policy are connected to the overall reform of the Common Agricultural Policy at the end of the twentieth century. In the modified concept of rural 
development, dubbed "LEADER superproject" by Cristopher Ray, the focus is shifted on utilising the endogenous resources and the unique characteristics of rural localities. This project-based developmental and institutional approach can be perceived as a common European answer for the challenges of the model of welfare state. The main goal of this European rural experiment was to encourage the local actors to take measures for their own well-being.

The enlargement of the EU also underlined the necessity of new methods of development. After the enlargement the existing regional (and rural) policies proved to be inadequate to achieve the stated goals for territorial cohesion. The limited success of reducing the territorial disparities in East-Central-Europe indicated that substantial change can be only achieved with synergy between the development programs of different sectors and additional efforts are necessary to integrate these development programs to become organic components of the localities.

In our opinion, place-based developments have a more complicated organisational and financial structure than locality-based developments. The financial sources of place-based developments include structural, cohesion, human or social EU funds too, and they form a very sensitive, integrated planning and programming approach with respect to the territorial aspects. This new development concept appeared in the Barca-report first (Barca, 2009, 2011)

This new concept anticipates that the place-based approach will improve the implementation and effectiveness of different sectoral policies with utilising the internal development potential of the localities and tailoring the planning and programming to the local circumstances. The fields of studies mentioned in the previous chapter can contribute with their research results to identify the different traits of localities (micro-regions). The place-based approach increases the significance of these different characteristics, and integrates them to the national and European development processes.

The core of place-based approach is the well-coordinated, multilateral and continuous communication between the actors and institutes from different territorial levels and different sectors (Fig. 1). This can also prevent the dominance of local and regional self-interest during the preparation of development policies. 
Figure 1 Key elements of the place-based approach

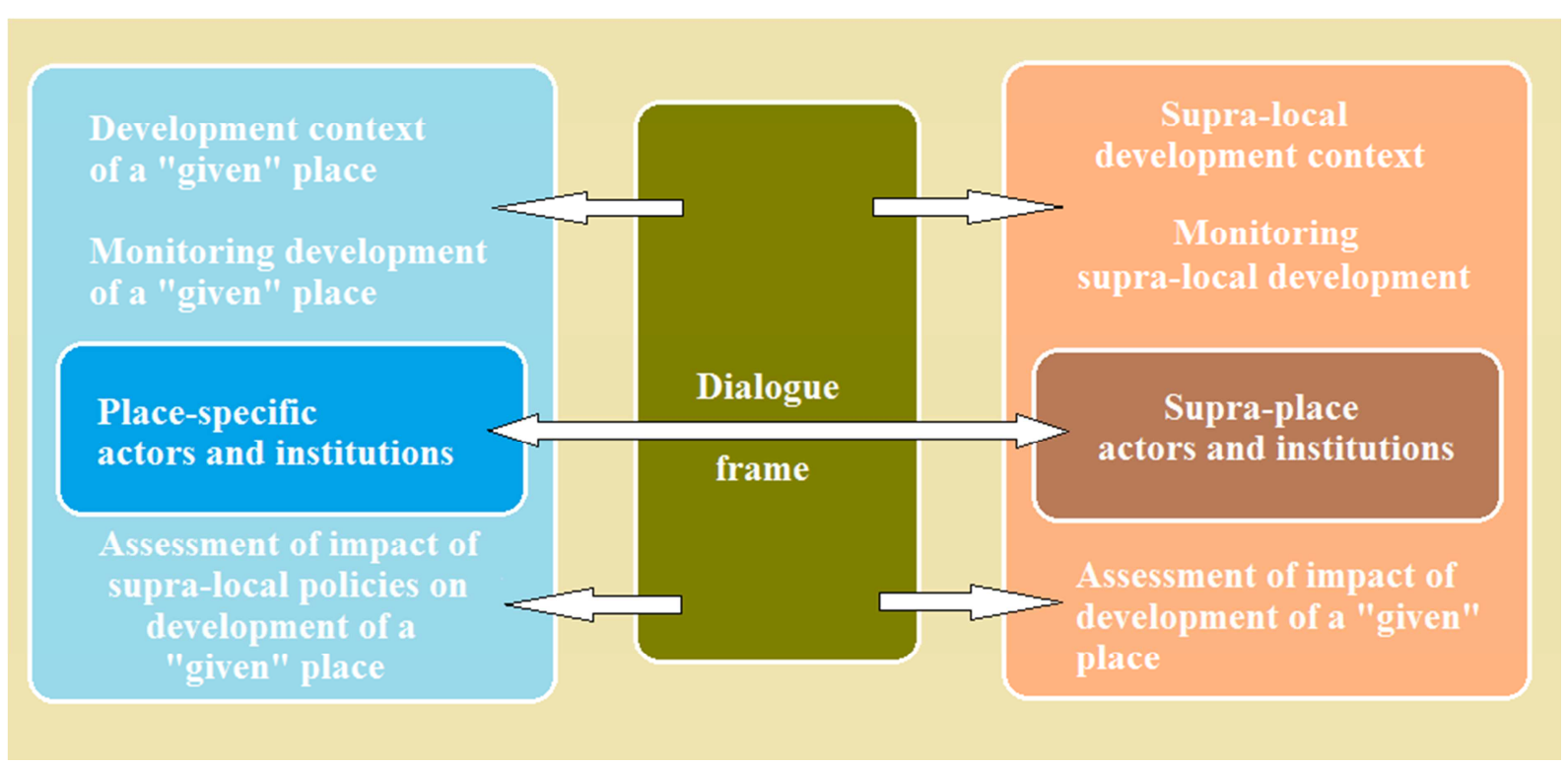

Source: Zaucha et al., 2013, p.13

In the report Place based territorially sensitive and integrated approach, which was prepared at the request of The Network of Territorial Cohesion Contact Points (NTCCP), the following main conclusions were outlined about the place-based development (Zaucha et al., 2013):

- All the necessary ingredients of the place-based approach are in place

- Countries' approaches may differ, there is no universal template of the place-based approach

- Territory can be considered as an important topic for cross-governance dialogue within the place-based frame

- Elements of the place-based approach which require more attention: the way territorial knowledge is collected, multi-level governance dialogue and its instruments

- Some policies already strongly benefit from territorialisation (e.g. transport policy, environment policy, urban policy, regional policy, spatial policy) which should be continued, but there is a further need to extend the place-based approach to some other policies with the substantial potential for territorialisation, mainly: R\&D policy, business policy, employment policy, education policy, health policy, and perhaps also fishery policy

Without doubt, the place-based development is more than a simple methodical improvement of the locality-based rural development already in use. Its main novelties are the focus on the synergies arising from the coordination of the sectoral policies in the development area, and the implementation of the already successful LEADER method in other areas, for example in the form of CLLD. 
Figure 2 The two approaches of community-led local development

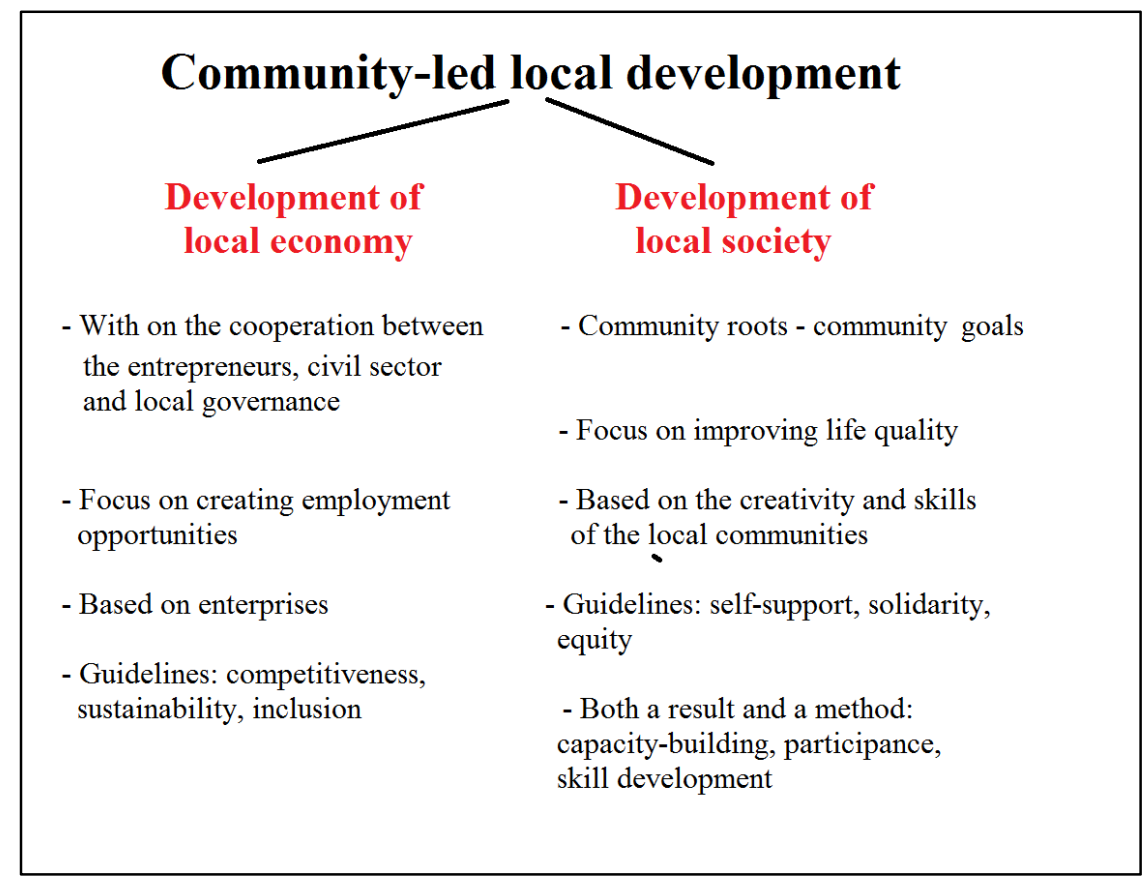

Source: Fekete, 2014

According to Fekete Éva, there are two paths of community-led local development (CLLD) (Fig. 2). One concentrates on the development of local economies and the other focuses on the improvement of local communities. The place-based approach will only be successful if both solutions are used, depending on whichever sector try to implement this novel thoughts.

Another key concept concerning the local characteristics is culture economy. After Cristopher Ray (1998), the term culture economies quickly became a keyword in rural development. Culture economies rely on the utilisation and capitalisation of local knowledge, which Ray considers a special product of the micro-region, and to some degree, a result of geographical determinism. The success of the wine routes across Europe and Hungary is a good example for the concept of culture economies in practice.

The spread of new approaches in the rural development also comes with some unfavourable consequences. A relatively new sociological phenomenon in the rural society, that the more and more exclusively project-based rural development lead to the formation of a new "project class". The power of members of the project class comes from their special knowledge about the often complicated project system and from their social connections (often with ties to the political sphere). Because of their fundraising ability, they became an essential part of local developments, and their absence in the most peripheral regions often lead to the lack of monetary funds and deepening poverty. On the other hand, the members of 
the project class are outsiders in the rural localities and often engage in projects which are not in accordance with the local needs (Kovách, 2013).

The concepts of decentralisation and subsidiarity dominated the rural development policy for a long time, which was favourable for the place-based development. Unfortunately, the financial crisis limited the availability of central funds. The governments made attempts to centralise the financing (but they left the project-based funding untouched) and also decimated the financeable topics. This increases the chance that the local development projects remain isolated, without multiplicative effects and positive influence to their surroundings. These trends are observable in Hungary too. The legislative changes, although did not take the responsibility of settlement development away from the local municipalities, limited their authority and available funds. Centralisation also included the local primary schools, which are crucial for the identity and self-organisation of the local communities. The scarcity of income sources and the legislative changes also made the connection to the microregional development and the foundation of rural development cooperations more difficult.

\section{PROBLEMS OF LOCALITY-BASED AND PLACE-BASED DEVELOPMENT IN THE HUNGARIAN COUNTRYSIDE}

In Hungary, the first development programs after the economic transition, which specially targeted truly rural areas, were some of the PHARE programmes. Shortly after the political and economic transition, in many micro-regions the rural settlements already created similar organisations like their Western European counterparts. After agreeing on the common development goals, they created voluntary micro-regional foundations, cooperations and organisations in the hope of financial support. This was the beginning of real cooperation based on subsidiarity and local attributes in many rural parts of the country (Zala-KAR Regional Innovative Association, Cserehát Municipality Alliance, Siklós-Villány Wine Route Association). The Hungarian Rural Parliament, founded in 1998, was the first attempt to bring together these local associations.

These associations were trailblazer attempts in Hungary for the better utilisation of local values, and mostly based on self-support (see Fig. 2). The enactment of Act XXI of 1996 on Spatial Development and Planning provided a relatively well-described path for their further development. It defined the micro-regions as an indispensable institute for the development of the group of settlements. The first National Rural Development Plan of Hungary was prepared for the EU accession and successfully integrated the multidisciplinary knowledge and visions 
of different fields and studies about the rural areas, unfortunately its new approach did not appear in practice (Csatári, 2005).

With the introduction of newer organisational and programming approaches, and with the changes in the distribution of EU funds, the main focus of the rural subsidies shifted to agrarian-rural development. In the development of the local economy, the emphasis shifted to the creation of new employment possibilities with the involvement of local enterprises (see Fig 2). In the programming period 2007-2013 local rural developments mostly connected to the third and fourth pillar of CAP, in the regional and sectoral programs the rural areas and specialities were not highlighted and did not provided sufficient funds either.

The Hungarian National Rural Network is a unique organisation in the Hungarian rural development. At its foundation in 2008, it mostly consisted of academic researchers and intellectuals longing for the renewal and development of the countryside (Glatz, 2008). After the end of 2010, it was operated within the National Agricultural Advisory, Educational and Rural Development Institute as a professional, quasi non-governmental umbrella organisation in regular contact with thousands of rural development organisations, associations, experts and local leaders, supporting the Hungarian rural development, especially local developments.

The legal sources of the European Agricultural Fund for Rural Development prescribe that each Member State shall establish a network. The national rural networks are formed from different stakeholders of the countryside in order to stimulate communication and exchange of information at regional, national and European level aiming the introduction the local development actions. These networks organise various professional events, operate communications tools and play an important role in the dissemination of proven best practices and of methods of local rural developments. At the European level, the national rural networks serve as an interface for the continuous dialog between national and local organizations and administrations taking part in rural development. The aim of the Hungarian National Rural Network (HNRN) is to organize governmental and local institutions, social organizations, professional bodies, business organizations that are involved in rural development into an information and cooperation network; as well as to coordinate their actions in order to the socio-economic development of the countryside together with the alignment of less developed areas and the effective use of supporting funds- to ensure this way the possible introduction of the tailor-made local development model.

According to the referring ministerial degree the HNRN had started its activity as a modern professional-civil network that paid attention to the bottom-up approach as well as to rural development solutions imposed "from above". It was operating as a meeting-dialogue place, 
as a body for collecting and transferring rural development ideas, and it served as a "sponsor" for other networks working in the countryside, too. Aiming for tailor-made local development the HNRN tried to unite all possible rural actors, because - as it has been demonstrated by researches of the private sector - the criterion of real innovation is cooperation or so called "network addiction". One of the biggest challenges for the Hungarian rural society is the renewal of the planning and programming activity and to find answers to the new challenges. In this process a well-managed Network could play a significant role supporting professional organisations and uniting national and European Union actors.

In the past years it has become a characteristic of local and transnational cooperation supporting the planning and development activities: a number of cultural and traditional festivals, niche rural publications, booklets and theoretical and practical information were published (Tab. 1). A lot of rural projects were realised with the support of the Network. Nowadays these projects have become really active local and regional programmes containing socio-economic and social elements. The bigger part of these projects could be connected to the traditional local development activities. But there were some projects that were able to fulfil the criteria of the tailor-made local development guaranteeing the synergy effect of more sectors (environmental protection, organic farming, rural tourism, community-building trainings, etc). These successful attempts indicate that the expression „rural development” based on the characteristics of the Hungarian countryside has to be interpreted in a broader sense; and further expansion and operation of the Network could provide significant support to additional professional planning and programming activities.

Beyond the traditional rural actors the Network has to set the following targets: to promote education and training, culture, corporate social responsibility, gender equality, environmental awareness and sustainability, as well as to unite local youth policy actors working in the field of youth protection (rural formal and informal communities, religious communities, regional governments, entrepreneurs, etc.).

Using the experience - and results in case of success - form the HNRN related planning, management and implementation of professional, thematic model programs, could help to develop the local actions into programs with national coverage. Concerning these sample programs tailor-made local developments should be preferred with the following expectations: results oriented approach, embracing community initiatives, local modelling of multifunded aids and the testing, practising and widely spreading of the adaptable "best practices". 
Table 1 In the period from 2012 to 2014 the following projects were carried out by the HNRN

\begin{tabular}{|c|c|c|c|c|}
\hline Number of projects & 2012 & 2013 & 2014 & Total \\
\hline Rural development project ideas & & & & \\
\hline 1. Preparation of LEADER transnational cooperation & 23 & 27 & & 50 \\
\hline 2. Knowledge transfer & 11 & 36 & 51 & 98 \\
\hline 3. Event & 53 & 90 & 111 & 254 \\
\hline 4. Publication & 13 & 50 & 67 & 130 \\
\hline II. Projects of national importance & 22 & 141 & 109 & 272 \\
\hline III. $\quad$ Projects of the Presidium & 67 & 34 & 17 & 118 \\
\hline IV. Projects of the Sections & & & & \\
\hline 1. Section: Competitive agricultural production & 14 & 14 & 8 & 36 \\
\hline 2. Section: Agro-environment & 4 & 3 & 6 & 13 \\
\hline 3. Section: Rural life quality & 52 & 43 & 3 & 98 \\
\hline 4. Section: LEADER & 10 & 10 & 9 & 29 \\
\hline Total & 269 & 448 & 381 & 1098 \\
\hline
\end{tabular}

Source: The authors' own collection.

The experts in in the registry of Hungarian National Rural Network can also provide valuable insights about the rural areas and development. The changes in their perception of the rural problems and rural development were investigated with the help of two surveys, which were conducted over the internet in 2010 and 2014 (Kovách - Czibere, 2014; Csatári et al., 2014). In 2010, 1023 surveys were sent out and 351 individuals responded. In 2014, the response rate was different for each question. From the 11609 registered members of the Hungarian National Rural Network, 1750 individuals opened the questionnaire, and the number of answers for each question was varied between 500 and 1000. Their answers point out the most pressing problems of rural areas, and the issues which require locality-based or place-based approach.

In one question, the participants had to select the eight most pressing problems from a list (Fig. 3). The difference is minimal between the answers of 2010 and 2014, which implies the persistence of main problems in the rural areas. This also suggests the ineffectiveness of the recent problem-solving attempts. In our opinion, some of these problems, like unemployment, rural out-migration and ageing could be more effectively addressed with the extended use of place-based approach, including the coordination of the existing programs of adult education 
infrastructure development and regional development, and utilising the endogenous resources of the localities.

Figure 3 The most pressing rural problems in Hungary

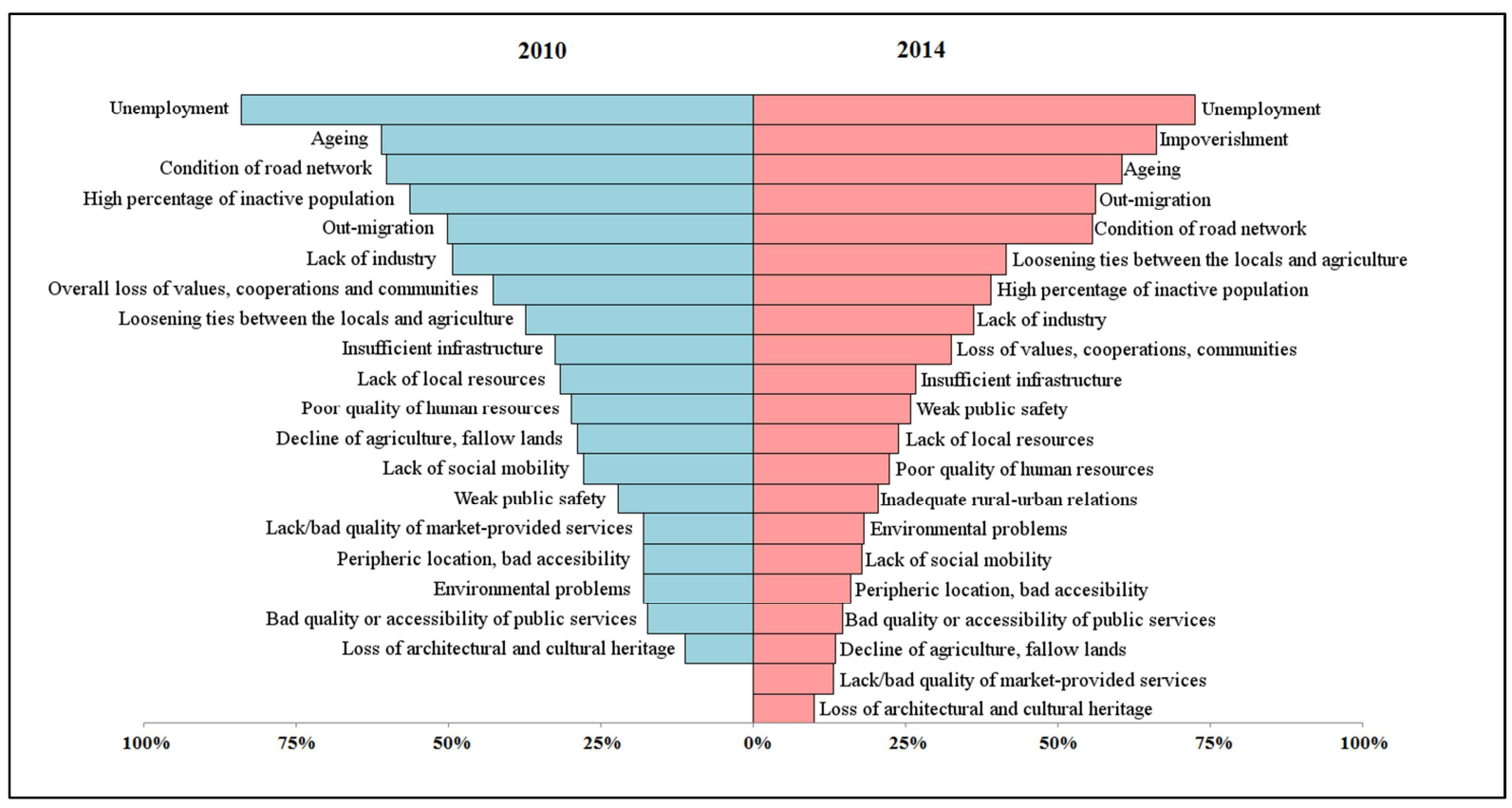

Ed.: Lennert J.

Source: Csatári et al., 2014)

The answers also highlight the loosening ties between the locals and agriculture, which also means the weakening ability of primary production to sustain local production. This finding also supports the tendency to shift the focus of rural development from agriculture to a more integrative approach involving other sectors too. It is also worth to mention that the availability of local knowledge, cooperation and local values is not especially endangered according to the respondents. These local resources can form the basis of locality-based and place-based developments. The results of the other presented question about the biggest hindrances of rural development also underline the importance of locality-based and placebased approach (Fig. 4). According to the respondents, the success of rural development can be increased with a more adequate allocation of funds, boosting the local knowledge in project management and with the involvement of local community in rural planning. It is also worth to mention that while the recent attempts to promote local production networks was at least partially successful, the inadequate allocation of funds became the biggest obstacle of rural development to 2014, which is in accordance with the critical opinions about the distribution of funds during the 2007-2013 programming period. 
Figure 4 The biggest hindrances of rural development

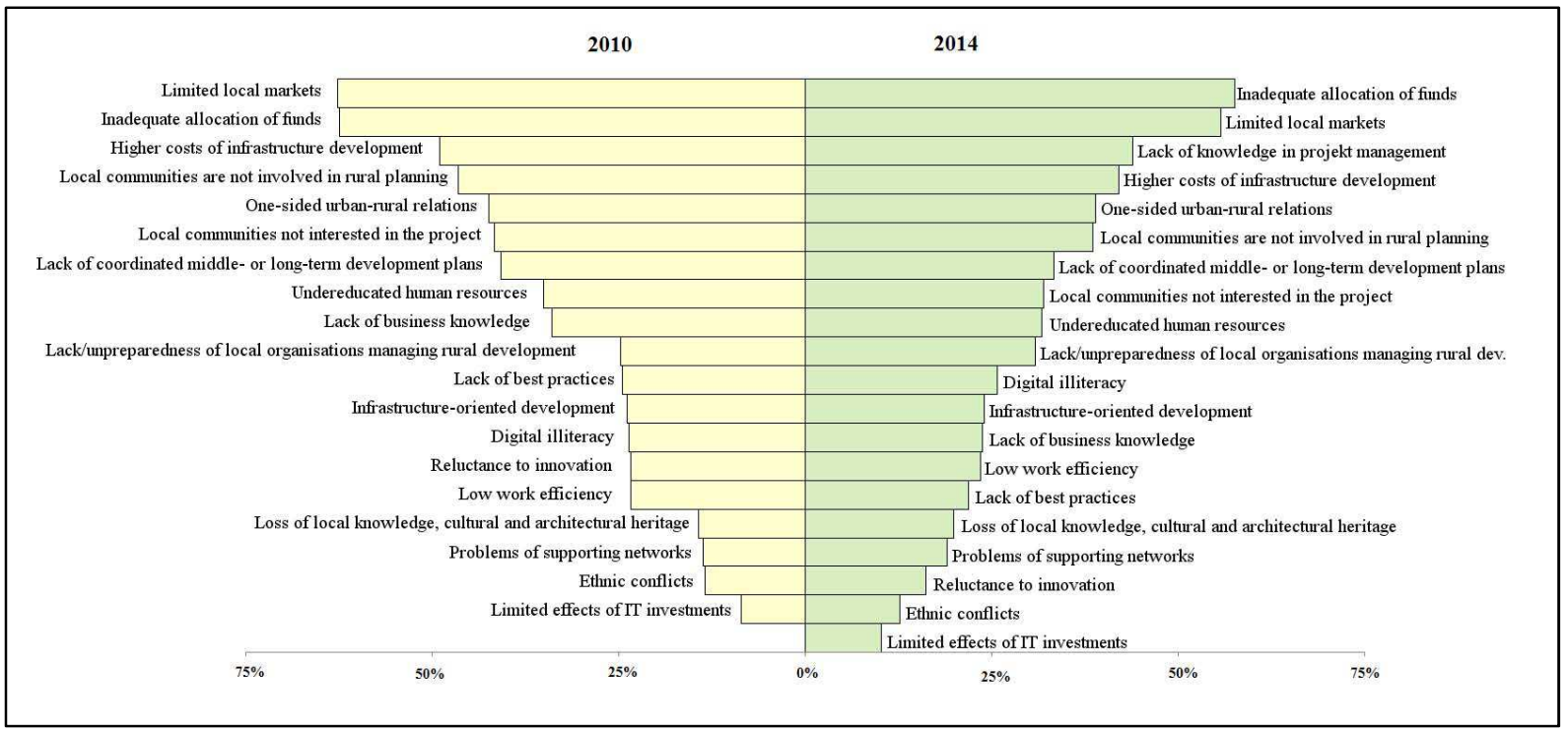

Ed.: Lennert J.

Source: Csatári et al., 2014)

The answers also highlight the importance of locally present experts of rural development. They possess the essential knowledge in project management which absence is considered as one of the biggest hindrances of rural development, and they can also facilitate the involvement of local communities into rural planning. The registered members of the Hungarian National Rural Network with their connections to rural development and with their strong local identity can fulfil this role.

\section{CONCLUSIONS}

In the financial and programming period 2007-2013 the EAFRD funds have become the primary financial sources for local development in the Hungarian countryside. Yet, their impact on the local communities was only moderate, mostly because the plans and implemented programs took the local characteristics and resources into account insufficiently. The local developments could not exceed the sectorial limitations and lead to complex, integrated spatial development. This is partly the fault of the dysfunctions in the administrative system in regional and sub-regional level. While the role of the NUTS2 statistical regions decreased, the counties and the newly formed districts were incapable to contribute to rural planning and programming. Similarly to some international examples, after the economic crisis, centralisation tendencies appeared in connection to rural development.

Our survey also proved that many experts live in the Hungarian rural areas (some of them are registered members of the Hungarian National Rural Network), who can also contribute to 
rural planning and development. They are also open to new approaches like place-based development, and they already realised that the limited effectiveness of rural development programs can be related to the lack of place-based approach. However, place-based approach will only be successful if the participating experts, entrepreneurs and institutes will be able to organise the necessary continuous multilateral dialogue. Also, in accordance with the shifting focus from regions to cities in the European development, a stronger cooperation between cities and rural areas is necessary, which, similarly to place-based development, also require multidisciplinary approach.

\section{REFERENCES}

Barca, F. (2009). An Agenda for a reformed cohesion policy. http://ec.europa.eu/regional_policy/archive/policy/future/pdf/report_barca_v0306.pdf (downloaded: 2015. 03.02. )

Barca, F. (2011). Conclusion. Alternative Approches to Developement Policy, Intersections and Divergences In: Regional Outlook 201. Organisation for Economic Co-operation and Developement, Paris.

Csatári B. (2005). Egy magyar vidékfejlesztési stratégia készítésének kísérlete. A Falu 20:(2) pp. 61-72.

Csatári, B., Farkas, J.Zs. (2010). Vélemények a magyar vidékről. A Falu 25:(3) pp. 9-19.

Csatári, B. (2011). Az új, 2020-ig szóló európai Területi Agenda üzeneteinek egy lehetséges interpretációja a magyar vidékfejlesztés számára. Falu-város régió 1. pp. 61-65.

Csatári B., Farkas, J. Zs., Lennert J. (2014). Tények és vélemények a magyar vidékről és Magyar Nemzeti Vidéki Hálózatról, Kutatási jelentés, Készült a NAKVI megbízásából, Ekisztika Bt., Kecskemét, p.72.

Fekete, É. G. (2014).

http://www.mnvh.eu/sites/default/files/g._fekete_eva_a_helyi_gazdasagfejlesztes_elmeleti_megkozelitesenek_lehetosegei.pdf

(letöltve 2015. 03.02. )

Glatz, F. (2008). Új vidékpolitika, MTA Társadalomtudományi Kutató Központ, p.270. Kovách, I. (2013). A felemelkedő projektosztály, In: Czibere I.- Kovách I. szerk. 2013: Fejlesztéspoltika-vidékfejlesztés Debrecen, University Press, pp. 157-168.

Kovách, I., Czibere I. (2014). A Magyar Nemzeti Vidéki Hálózat szervezeti és hálózati működése, Kutatási jelentés, Készült NAKVI felkérésére, Donátum Bt., Debrecen, p.97.

Krugman, P. (1998). Space: the final frontier. Journal of Economic Perspectives, 12. 2. pp. 161-174.

Krugman, P. (1991). Geography and trade. The MIT Press, Cambridge, US, 156 p.

Ray, C. (2013). Nemzetközi együttmüködés a vidéki területek között: az EU vidékfejlesztésének politikai-gazdasági elemei. In: Czibere I.- Kovách I. szerk. 2013: Fejlesztéspoltika-vidékfejlesztés Debrecen, University Press, pp. 17-39.

Ray, C. (1998). Culture, intellectual property and territorial rural developement, Sociolgia Ruralis, 38. (1) 3-20.

Zaucha, J., Swiatek, D., Stanczuk-Olejnik, K. (2013). Place-based territorially sensitive and integrated approach, Warsaw, 2013. p.134. 